\title{
Women Victims of Domestic Violence: Analysis of Their Perceptions of the Criminal Justice System in Romania
}

\author{
Imola Antal ${ }^{1}$, Júlia Szigeti ${ }^{1}$, Maria Stoleru ${ }^{1}{ }^{*}$ \\ ${ }^{1}$ Babeş-Bolyai University of Cluj-Napoca, Department of Social Work, 128-130 21 Decembrie 1989 Bld., 400604 Cluj-Napoca, \\ Romania
}

KEYWORDS

Domestic violence

Criminal justice system

Police response

Women's perceptions
ABSTRACT

Criminal justice interventions are important to reduce domestic violence and protect women. In this study we will tackle the unwillingness of women in two regions of Romania to press charges and the failure of the criminal justice system in providing them protection and justice. "Why don't women press charges?" was the main question that stood at the basis of the international research WOSAFEJUS1, where Babeş-Bolyai University (UBB) was the main Romanian partner through its Faculty of Sociology and Social Work. In our paper we will analyse the studies relevant to the field of domestic violence and we will pay a special attention to those that take into consideration the functioning of the criminal justice system. We will present a preliminary analysis of the women's perception of the criminal justice system in Romania. Our results are based on 76 semi-structured interviews with women in a situation of domestic violence. Atlas.ti was used to aid a thematic analysis of the qualitative data. The results will highlight women's expectations regarding the justice system, the perceived usefulness of the legal intervention as well as the main factors that come into play when they decide to stay or to leave the criminal justice process. Even though in most of the cases police intervention can't or doesn't provide safety and the rapid elimination of danger, the importance of non-legislative factors of intervention has nevertheless been emphasized.

\footnotetext{
* Contact address: imolaan@yahoo.com (I. Antal)

1 WOSAFEJUS (Women Safe Justice) - Why Doesn't She Press Charges? Understanding and Improving Women's Safety and Right to Justice, is a transnational project - coordinated by the Carlo Cattaneo Research Institute in Bologna, and financed by the European Commission's Daphne III Programme.
} 


\section{Introduction}

Feminists have been campaigning for the criminalization of domestic violence since the 1970s, considering that domestic abuse should be seen and condemned as any other violent crime. In many countries there has been a plethora of policy initiatives aimed to develop criminal justice approaches to domestic violence. These included generally pro-arrest and increased prosecution and conviction and suggested that criminal justice interventions can be used to deal with domestic violence and to reduce violence (Hester 2005).

Research in the 1980s in the United States initially indicated that use of arrest helped to reduce repeat offending in relation to domestic violence. In the 90's arrest studies were carried out in several countries (US, UK, Canada, etc.), aiming to evaluate the efficiency of arresting on reoffending and the safety of the victims. One of the first and most important arrest studies was the Minneapolis experiment in the US (Sherman and Berk 1984). The Minneapolis experiment found that when the offenders of spouse assault incidents were not arrested, the prevalence of official recorded re-offending within six months was $21 \%$; while the re-offending rate of similarly situated suspects who were arrested was $14 \%$. According to Garner and Maxwell (2000), following the Minneapolis domestic violence experiment and 6 other important police arrest studies in the US, the policy debate on alternative police responses to domestic violence is no longer about alternatives to arrest but alternatives to what the police and other agencies should do after an arrest. Later studies found out that while arrest may act as a deterrent for some domestic violence perpetrators, it does not appear to have such an effect on the more chronic domestic violence offenders (Hester 2005). Regarding the court outcomes, generally there is a relatively small amount of research, usually showing that the rate of convictions is really small compared with the charges or emergency calls.

Besides all the positive outcomes of criminal justice studies, according to Bailey (2010), research indicates that criminal justice interventions are unlikely to be effective in addressing what is a social, political, and economic problem. For this reason, a criminal justice solution should be part of broader domestic violence policies that address the complexity of this issue. 
In Romania the criminalization of domestic violence got some attention only in the last ten years. During the communist regime, domestic violence was denied, just like any other social problem. Even though during the communist regime an official policy was launched on the equality between men and women, this had nothing to do with reality. Even though in 1982, Romania ratified the UN Convention on the Elimination of All Forms of Discrimination against Women - CEDAW - considered to be a very important legal instrument for the affirmation of women's rights, inside the country there was a tough legislation that supported a pronatalist policy "that valued women especially from the point of view of fertility" (Muntean, Popescu and Popa 2000). After 1989, at first, there were external mechanisms for raising awareness on the domestic violence phenomenon. They acted through the ratification of international documents, the promotion of human rights and implicitly, the incrimination of partner violence and media coverage of international events concerning domestic violence (Popescu and Muntean 2000).

In 2000 new provisions were added to the "Violence and Corporal Injury" article of the Romanian Penal Code, through Law No. 197 of 13th November 2000, which represented the first public acknowledgement of domestic violence as a social problem in Romania. Subsequent applications revealed that the changes to the Penal Code were inefficient and insufficient. Consequently, the necessity to harmonize legislation with community needs, as well as the pressure from the civil society, which was fuelled by the prevalence of domestic violence cases, led to the promulgation of Law no. 217 of 29 May 2003, which provided for the prevention of domestic violence and the action against it. This law, voted in 2003 which doesn't insist at all on the safety of the victim but rather on the prevention of violence through a system of family assistants, a structure that doesn't actually exist, it is rather an example of resistance to change than a real effort towards the criminalization of domestic violence offences.

\section{Data and research in Romania}

The scientific interest for domestic violence follows the same pattern as the legal and social interest for the topic in the ways in which it has been 
discussed and researched. There are only a few studies in Romania which provide valid research data regarding domestic violence and most of them are prevalence studies. According to the Survey on Violence against Women (Gallup 2003), 21\% of the women had been victims of physical abuses in their lives, $6 \%$ of the women in Bucharest have suffered physical abuses during the last year (Gallup 2003). According to the results of the National Research on Domestic Violence and Violence in the Workplace (CPE 2003), 14.3\% of the whole population of Romania, $17.8 \%$ of women respectively, state that they have been victims of one or another type of domestic violence at a certain point in their lives. $6.8 \%$ of the adult population in Romania reports physical domestic violence which is almost four times more frequent against women $(10.5 \%)$ than against men $(2.5 \%), 1.4 \%$ of the adult population in Romania reported sexual domestic violence. Sexual violence is only reported by women $(2.6 \%), 12 \%$ of the divorced women reported marital rape, versus $2.3 \%$ of the married women or $1.8 \%$ of the widows. The Reproductive Health Survey's results show that of 15 - 44 years old ever married women 28\% reported verbal abuse, $15 \%$ physical abuse and 3\% sexual abuse.

Regarding the male sample, $51 \%$ of male who are currently or previously married reported being verbally aggressive with their partners during their lifetime, $21 \%$ admitted being physically aggressive at least once and $0,6 \%$ admitted being sexually abusive. The data shows a slightly reduced level of domestic violence perpetrated by males in 2004 than in 1999 , the reported physical violence decreased from $29 \%$ to $21 \%$ (Ministry of Health 2005).

We can also find data regarding the perception of the police or other agencies. According to the Gender Barometer (Gallup 2000) in 2000 more than half of the population still believed that domestic abuse is a private matter (63\%) in case of which no one or relatives should intervene. Only $28 \%$ thought that the police should intervene.

According to the Survey on Violence against Women (Gallup 2003) of those who experienced physical abuse within the family $(\mathrm{N}=193)$, only in $17 \%$ cases she or anybody else went to or called the police to file a complaint (last time when they were aggressed). On the following we represented the level or the reasons of dissatisfaction of the respondents with the intervention of the police. More were dissatisfied (63\%) than satisfied (37\%), 
and $66 \%$ of those who were dissatisfied mentioned that the reason was that they didn't do anything. Of those who didn't file a complaint, 53\% didn't give the reason, $21 \%$ said it was not so bad, $7 \%$ were afraid or thought it would not help.

In the study National Research on Domestic Violence and Violence in the Workplace-Romania (CPE 2003), during the individual surveys the respondents were asked about who should intervene when someone has been beaten by her/his partner, wife/husband. The majority of the respondents $(61 \%)$ still considered that the domestic violence is a private matter, in case of which family or nobody should intervene. 33\% considered that the police and 3\% that the Prosecutor's Office should intervene.

In this survey the percentage of those who filed a complaint at the police against the perpetrator was $20 \% .47 \%$ of those who filed a complaint were satisfied with the way police officers dealt with their cases, which is a little bit more compared with the results of the above presented survey. $6 \%$ of the respondents who filed a complaint knew that the offenders had been convicted on criminal charges.

Although these numbers indicate a high rate of prevalence of the phenomenon, the number of those that ask for the help of social services or other specialist services is a lot smaller. Official data are provided by the National Agency for Family Protection (ANPF 2009). According to these data, the number of domestic violence cases registered and reported varies from 2937 (in 2005) to 11537 (in 2008) the total number of cases reported during 2004-2009, first semester is 53720. In the last 2 years the number of reported cases grew. The National Agency for Family Protection (ANFP) collected data from state agencies and NGO-s which provide services for victims of domestic violence.

We have more precise statistical data concerning the number of criminal files. According to the statistical data coming from the Superior Council of Magistracy (2010) the total number of criminal cases sent to courts between 2002 and 2009 varies between 128 (in 2006) and 242 (in 2002). The number of files did not increase after the adoption of Law no. 217. 2002 year saw the highest number of criminal files (242) sent to courts, while in 2008 there were only 174 . As for the percentage of different crimes for the 8 years that we studied, the highest percentage (41.9\%) were criminal files for 
homicide, followed by family abandonment $(21.5 \%)$ and by hitting and other violent acts $(15 \%)$. The percentage of homicide cases is higher than the total of the percentages of the other crimes of physical violence $(36 \%)$. The smallest number of criminal files was represented by those for deprivation of liberty $(0.5 \%)$ and rape $(0.3 \%)$.

The Gender Theme Group performed a research in 1999: Victims of Domestic Violence: Children and Women (Muntean, Popescu and Popa 2000), a qualitative analysis of 40 interviews with women victims of domestic violence. This study revealed the following aspects with regard to police intervention:

- The most frequent situation is that police refuses to intervene in absence of a divorce decree or a dead body. Muntean et al. (2000) presents the paradoxical situation: nevertheless, with no other alternative available, police is the only institution authorised to intervene.

- Another situation occurs when the police officers directly or indirectly encourage violence by blaming the victim or by trying to mediate the situation (saying that if she minds her own business things will go better).

- Giving fines for disturbing the peace, which are paid from the family budget and which can subsequently aggravate violence. The victim's feeling of being guilty is intensified by the intervention of the police which can give a fine to both partners.

- A fourth situation is total reluctance to call the police, because of fear, because they don't expect any positive result or because of shame.

- In case of police intervention, this can be characterised by goodwill or by expressing their powerlessness.

In 2006 a group of researchers from APFR Timisoara analysed 51 domestic violence cases trialled in court. According to their results in $67 \%$ of the cases women maintained their declarations, and only in $11.2 \%$ of the cases they withdrew their preliminary complaint. $9.8 \%$ of the perpetrators were arrested during the trial, and in most of the situations the punishment 
was a fine. In 4 situations the perpetrators were imprisoned (all of them for severe crime).

\section{The WOSAFEJUS research. Methodological aspects}

In order to establish a detailed and triangulated picture of how the Romanian criminal justice system functions, the WOSAFEJUS research used quantitative analysis of domestic violence related case files in the courts and prosecution offices from Cluj and Iasi counties and ethnographic observations at the courts, combined with in-depth interviews with individuals experiencing domestic violence and with staff from the criminal justice system and other agencies. The Atlas.ti software was used to aid a thematic analysis of the qualitative data. We based our present study on the preliminary results of the interviews with women.

Through in-depth interviews we wanted to explore different areas: why women do not use the criminal justice system (call the police, press charges, etc.); why-where-how-when they decide to use it, to press charges; what happens when they use the criminal justice system, how they perceive the intervention of the police, prosecution service and the courts.

This means looking at how women perceive and represent the criminal justice system, understanding what women's needs, requests and expectations from the system are in order to investigate what prevents/motivates them to use it. What their experiences are, if any.

The perspectives and experiences of those victimized were obtained via interviews with 76 victims of domestic violence, 30 women from Iasi, 46 women from Cluj. We paid special attention to women from ethnic minorities (11 ethnic Roma and 15 ethnic Hungarian women from Cluj). Most of them were contacted via social services or NGO-s offering services for women, initially via an information letter to ask if they would be willing to be interviewed.

For the creation of our sample we took into consideration the following criteria: identifying those women that used/didn't use the criminal justice system, women with/without children, aged 19-70, living in urban/rural areas, from different social classes, with different levels of education (no high school diploma - university graduates). 
The analysis of the interviews revolved around two main themes: using and not using the criminal justice system, 9 secondary themes (obstacles to using the criminal justice system; emergency calls and women's contacts with the police at the police station; women's reporting/not reporting violence; women's withdrawing statements/complaints/attempts to resort to the justice system; legal information; relevant persons / professionals' attitudes towards women's use of the criminal justice system; women's view of criminal justice system; other court involvement; support) and 47 categories (e.g impact of children on decision making, perpetrator's behaviour post-incident, feelings or fears about using criminal justice system, victim satisfaction, view of courts, view of police, view on outcome, what could have been done differently etc). The perceptions of the use of the criminal justice system will be analysed during each step of the legal intervention.

\section{Analysis of the results}

\section{Obstacles of using the Criminal Justice System}

Regarding the reasons for not using the criminal justice system, we indentified two main categories, on one hand reasons related to the women's situation and, on the other hand, reasons related to the perception of the criminal justice system.

In connection with the first category of reasons women highlighted the following obstacles:

Fear. Fear of more violence, fear of endangering the safety of the children:

I didn't even think of calling the police because I knew I would have to leave the house, the children as well (G.I).

Commitment towards the partner. Hope that the violent behaviour of the partner will change, forgiveness and commitment towards the marriage, even though there is an incongruity between the current relationship and the relationship they wish for: 
I didn't think of calling the police, even though this wasn't the first time it happened, I thought he'll change and that we'll manage to get along without involving the police (C.T.E).

Children. The existence of children is a key factor in decision making:

Yes, I know and I'm aware that what he did was against the law, but I couldn't do anything because he is the father of the children (Sz.K.).

Lack of resources. Poor financial resources and the lack of social support:

No one would have come, they don't want to get involved, not even my family and I didn't have witnesses...so how could you expect the others to believe you (A.A).

Attitudes regarding violence. Violence is perceived as a problem that needs to be solved inside the family, the belief that abuse is the consequence of their behaviour.

The perception of their role as mothers and wifes. the wish of women to have a united family, no matter the circumstances. As for the unity of the family, as mothers, women consider that the presence of both parents is important, in spite of the violence, and as wives, they want to offer unconditional love:

He hit me a few times, but I forgave him. He apologised, he said he'd change... so I forgave him and got over everything (A.B.).

I consider that children are children and that they must live together with their mother and their father and not... I don't know what can be done (M.A.).

Perception of the criminal justice system by the women who don't use it

Other obstacles add to those presented above. They are the result of the perception of women victims of domestic violence of the criminal justice system. Women who don't use the criminal justice system perceive police intervention as being inefficient, inadequate for domestic violence situations. The most used procedure in case of domestic violence is to give a fine, procedure that is not seen as a factor that can increase the victim's safety. Moreover, in most of the cases, this procedure has consequences for the victim, who suffers more violence, or she is forced to pay the fine:

Yes, I thought about it... what could they do to him? Maybe give him a fine, they couldn't do more. That's all... (S.D.) 
An example of the way in which police intervenes in the community:

If he fights or he hits his wife, he's given a fine and then they let him go. When they come back, they hit their women because they called the police and they were given a fine. In the end the woman who called the police is forced to pay the fine (S.D.).

On the other hand, police intervention is perceived as being fragmented, each violence episode is addressed as if it were unique, the violence dynamics is not taken into consideration, the cyclical character of the violence is addressed just like in the situations where the victim and the offender don't live together:

Maybe they would come once to separate us till things calm down, to give us a warning, so that violence stops for a moment, but afterwards violence starts all over again. Go to the police over and over again? He is given a fine over and over again... this doesn't look like a solution to me... he would be upset with me because I did that, he would calm down for a while and afterwards, you know how it works...this will cause more problems... I try to avoid that, no, I wouldn't be afraid to call the police if necessary, God forbid, of course I would... no, I wouldn't be ashamed, if necessary, no (F.L.).

Previous negative experiences with the police were also mentioned:

I don't think it is very useful because I called them last year when some people attacked me in the street and they didn't help me. I don't really trust them. I think they'd scare him, but I wouldn't be given more help (L.S.).

\section{Police emergency interventions}

When do women contact the police?

We found that women contact the police after repeated episodes of violence (only in a few cases police intervention was called for during the first incidents of violence) and when they feel that violence becomes unbearable, dangerous, with unpredictable consequences (in the case of serious violence episodes that need immediate medical intervention, or when they fear for their physical safety and the safety of their children). We also found that, before calling police, women look for the support of family members, friends, actually preferring the support of people close to them. 
The involvement of children

In most of the cases women mentioned that children were present during violent episodes, their main response being that of support, attempts to look for help, the wish to protect their mother and involvement in contacting the police:

(...) he used to hit the girl and me, when I made a sign she went and brought the police (K.I.).

My boy encouraged me, mom go to the police, the girl was afraid, she was ashamed of colleagues and neighbours (R.A.).

The women also mentioned those situations in which children are scared by the violent partner in order to prevent them to ask police for help. Perpetrators create confusion in children regarding who is responsible for the abuse. In these cases, they often undermine the mother and use children against her:

I was in a real and big danger.... The girls understood and helped me. They gave me advice and supported me. They even pushed me to do what I did. On the other hand, the boys totally agreed with their father, not with me. And no... They only answered their father's wishes, not mine. On the contrary, I had many troubles with them and the conflict of opinions between us grew bigger... They didn't understand me. They don't understand me today either (G.R.).

\section{Police intervention}

Regarding this aspect we tried to identify the relationship between police intervention and women's expectations, analysing the level of satisfaction as well as the perceived usefulness of emergency interventions. Analysing women's expectations, we found that they need a fast, immediate and oriented intervention in order to stop violence. The need for safety is considered a priority. Another important aspect highlighted in the interviews was addressing emergency calls with all the seriousness needed, the ability to assess the risk and the danger even in the situation when the woman is forced by the offender not to give a statement, not to open the door or to deny the violence. 
As for the actual police intervention, we identified the following possible means of intervention:

1. The police officers are worried about the safety of the victims, they do something on spot to protect them and then they leave. Providing physical safety during violence escalation is important for women, but it is not a solution that can prove efficient on the long term:

Police came with me after he beat me and my mother. The policemen stood in front of our door until he left... I was left alone with the children. The policemen left as well. No warning for him, nothing. (...) I thought they were going to arrest him. Nothing happened. Then I ran away from home (A. J.).

They gave him a warning, that he shouldn't do such things anymore, because he has a child. After a while they came, they calmed him down and they left. This happened over and over again (J.I.).

2. Make the offender promise he will not beat his partner any more. Women say that the promises of change made by the offenders don't work, that is why they need violence to be recognised as an offence:

The policeman said: 'If she withdraws the complaint, you will have to make a written statement that you will not beat her anymore'. He wrote it but he has forgotten about it. He still beats me (Sz.K.).

Police made him give a statement that he would not beat me anymore. He gave a statement and he still beats me. Police has already had enough of me. They said I should go to court. But no one cares about me there (A.F.).

3. Apply a warning or an administrative fine to the offender. We found that in some situations giving a warning or an administrative fine can slow down violence. In other situations these measures don't have the expected result:

I called the Police, they gave him a fine so that he would mind his own business. Nobody has paid the fine. He has never paid it. The fine is still unpaid today. The police used to give him a fine and then leave. I called the police dozens of time (M.C.).

I called and waited for them to come and then... They gave him fines or they told him: so they told him to leave me alone. Yes, it was good. I didn't have any problems No... Police did their job. I was pleased (M.M.).

4. Apply a warning for the perpetrator and for the victim. In cases where both partners are held accountable by giving them a warning, abuse is not 
recognised as being an offence. This measure discourages the victim from using the criminal justice system and holds both partners accountable for domestic violence. As presented in the following example, the case is addressed as if it were a matter of disturbing the peace, thus denying violence:

Once I called the police from the park. I needed their help. I was beaten by my husband and no one intervened. Police came and gave a warning to both of us for disturbing the peace in a public place (D.C.).

5. Punish the victim. The victim and the offender switch roles, the violent situation is not addressed as a whole. Thus, all the previous steps undertaken by the victim in order to receive protection and to sound the alarm on her situation are ignored. In this way the offender is absolved from responsibility:

Once he broke a mirror and beat our child too, he was a baby, then I couldn't control myself, I took a knife and I told him not to dare to beat us again. I scratched him, there was blood, it was a superficial wound. He called the police, one of the policemen knew us already...they had been to our house for around 14 times and didn't do anything, just a few warnings and once fine. Police saw many times that I had bruises; I even gave a statement 3 times. Nothing happened. Do you know what happened now? They hand-cuffed me and they took me away in front of the child (B.G.).

6. Take the offender into custody at the police station. Taking the offender into custody is seen as an efficient measure by most of the women living in a serious violent situation, but has only short term effects:

They would take him to the police station, and then let him free. He would then come back home and beat the hell out of me (Sz.K.).

On the other hand we found that in spite of similar measures (fine, warning), women's level of satisfaction is different. The level of satisfaction and the victim's trust in police is higher when police gave realistic information, specific to women's needs, when they showed respect towards the victim, made the offender aware of his responsibilities and assured the victim they will come back in case of a new violent episode.

Should we analyse the efficiency of the intervention from the point of view of victims' safety, women that have experienced serious violence for a long time confirm that, following police intervention, violent partners used 
intimidation and threats (death threats), and that they had to experience even more violence. The severity of the violent situation diminished especially in the case of women that asked police for help starting with the first episodes of violence or in the cases where the level of danger was small.

\section{The criminal investigation}

Many women didn't file a preliminary complaint, and a high percentage of those that filed a complaint have withdrawn it afterwards. There is a variety of reasons for not filing a complaint.

Not knowing the procedures or the possible consequences. Many of the women weren't informed by the police officers about the importance of filing a preliminary complaint:

I didn't know I had to file a complaint, they (the policemen) didn't tell me, they didn't tell me about the evidence either (M.M.).

We can also see reluctance towards filing a complaint in those situations in which the victims don't anticipate the consequences of their report.

Previous negative experiences with the criminal justice system - women that had already been confronted with the criminal justice system's powerlessness were discouraged from reporting the violence:

Yes I called from the first time he started to become violent. Even his mother went and reported him to the police and they gave him a fine. He hit her many times and she went and paid the fine for him. So we didn't gain anything, either I called the police or someone else did, nothing happened (R.D.).

Their own safety, the fear of violence escalation in case they file a complaint.

The wish to protect the offender for various reasons (children, dependency, loyalty etc.):

I would like to know him away, arrested, and to live a safe life, without him. But I didn't want to do this to my child... It is his father, how could I put him in a jail (A.A.).

Filing a preliminary complaint is usually characterised and followed by shame, fear of violence escalation, of the offender's revenge, fear of the economical consequences, fear of losing friends and family support. In some 
cases these feelings were accompanied by positive feelings such as 'liberation', 'relief', 'peace' as a result of the fact that someone, who has the authority and the possibility to intervene, listened to them and believed them in a safe environment.

Withdrawal may take place at any moment of the intervention. It usually takes place at the police station. The reasons for withdrawal are similar to the reasons for not using the criminal justice system or to those for not filing a preliminary complaint; they are fear of violence escalation, financial and/or emotional dependency on the offender:

I never got to court because he made me withdraw my complaint. He threatened me, I was afraid, so I withdrew my complaint. The problem is that he has 7 brothers, they are 7; I, on the other hand, am alone, there is nobody to help me. His brothers, whatever I tell him, will lash out at me (I.D.).

The files can be closed at the level of the Prosecutor's Office for different reasons, e.g. lack of evidences, or the offender may be punished by the prosecutor who gives him an administrative fine.

Many women were not informed of the Prosecutor's Office decision to close the file. The only thing they knew was that they wrote many statements, but nothing happened:

So I filed a complaint and nothing happened afterwards. No one came to talk to me, the file wasn't sent to the Prosecutor's Office, it never got to court, it was never prosecuted. No (B.I.).

As for the perceived usefulness of filing a complaint, we observe disappointment with regard to making the offender aware of his responsibilities:

I wanted him to be a bit afraid of authorities and of Romanian legislation. That they will make him realise that playing with someone else's life is not something to be done. To make him aware that he is responsible of his deeds. But no... Unfortunately... It wasn't difficult to file a complaint. It was a shock and shocking to me to hear the answers the police gave me, that they can't do more than give him a fine 2 times, 3 times... 20 times (R.B).

Nevertheless we found that in some situations there was a feeling of satisfaction as a result of collaborating with the authorities and of their behaviour: 
I was pleased, I understood that they couldn't do more... but they were there for me (D.N.).

\section{The trial}

Of the total of 76 women interviewed, only 2 actually went to court. In both cases the punishment given was a fine. Both women divorced until they reached this phase - probably the main reason for which they didn't withdraw their complaint and both of them were supported by representatives of a women's organisation, respectively of a shelter during the court case.

The women were disappointed by the long duration of the trial, by the lawyers' and the judges' behaviour (one of them changed 3 lawyers because they treat her case as a conflictual situation and not as a violence situation) but most of all they were disappointed by the outcome of the court case, by the punishment received by the offender. Nevertheless both women think that everything was worth it, they felt powerful:

I could do it until the end, I could defend myself (D.C.).

\section{Other court involvements}

Most of the women chose separation or divorce as a way of overcoming violence. A certain amount of financial independence makes a difference when taking the decision to file for divorce. Many women file for divorce, then they withdraw, and this happens many times, most of the times children being the reason for reconciliation:

We were reconciled for the children, I saw how glad they were at the meetings, but to no avail, violence continues, they suffer as well (S.K.).

In the case of a court case, as well as in the case of a divorce, women face the difficulty of convincing those that know about the violent situation to testify as witnesses in court. Victims of domestic violence say that the support they received mainly came from professionals. On the other hand there was some pressure seen from family and relatives in favour of not reporting violence and not involving the criminal justice system. 
Unfortunately neither divorce nor separation don't provide safety to the victims. Women with children especially say that violence episodes can continue even after separation, because the ex-partner still lives in the house or because of the visiting hours set by the court.

\section{Discussions}

In our research we have found two categories of obstacles which hold back women from using the criminal justice system. Firstly, those which are related to the women's situation, including her feelings (fear, shame and the hope that everything will be all right in the future), the lack of material resources, attitudes from the family (including children's attitudes) and, secondly, their perceptions of the criminal justice system (police intervention is seen as inefficient and inadequate, fragmented or not to be trusted). Our findings mirror the findings of the international research studies. Victims may experience some level of fear about the consequences of seeking legal assistance. Some victims may fear that the abuse will escalate in severity and frequency (Johnson 2007). Other victims may not call the police because of their perception that legal intervention leads to separation (Felson et al. 2002) or because of the hope that the abuse will stop without legal intervention. Fear of financial dependence, for the welfare of their children, and the lack of support from families and friends, combined with their own desire to save their marriages are also obstacles in their seeking legal assistance (Davis and Smith 1995).

As we can see, these obstacles (fear, lack of social support, myths) act on many different levels, from the individual, family (relationship with the offender and children), and community (intervention of the police, lack of services), to larger social and cultural levels, resulting in complex, powerful barriers when it comes to use the criminal justice system. This shows the importance of approaching intervention on more levels.

Warnings and fines seem to be inefficient measures in most of the cases, not to mention fines applied to the victim or arresting the victim. Regarding the emergency interventions of the police, our findings show that the only effective police intervention which provides safety (for a short period) is the police custody of the perpetrator, which is very rarely applied. 
Writers in the field mention that police in Romania are practically helpless in domestic violence situations. Muntean et al. (2000) consider that when the police are called, and they answer the call, the measures taken can boomerang on the woman. Besides the fact that these measures tend to be fines that affect the family budget, police officers don't usually take into account the fact that when they're gone the offender probably becomes more violent.

According to Radu and Radu (2004) following an emergency call, the police, in practice, arrive at the crime scene, apply an administrative fine to the aggressor and leave, because if the injured party states explicitly that they don't intend to file a complaint, the police are unable to take any other measures (removing the aggressor, or arresting the offender).

Concerning the legal classification of offences from the perspective of the police, it is important to mention Law no. 61/1991 on punishment of the offences against rules of social life and public order. According to this law, 'chasing away the husband, the wife, the children as well as any other dependants' is an offence. This law also punishes insults, swear words, threats of violence shouted in public against a person, as well as disturbing the peace of those living in the same building through loud noise or vociferations. This document often creates a framework for police intervention (Muntean, Popescu and Popa 2002).

As regards to Law no. 61/1991, this law stipulates that a police officer can refer the case to the court and ask for imprisonment. Even though in this case there is a rapid procedure, 24 hours, with an immediate enforcement of the punishment, this provision is never put into practice in cases of domestic violence (Muntean, Popescu and Popa 2002).

Important findings of our research were those related to the non-legal factors of the police intervention. Following police intervention some women talked about feeling satisfied with the seriousness and respect with which they were treated by the police. Also they came away feeling they were realistically informed.

Similar findings were described by Russel and Light (2006). According to them there are three dimensions of police response that had an impact on the victims' satisfaction and were observed in other studies: integrated team when police, victims and all actors of the criminal justice system work 
together. A second dimension of police response was observed as being efficient, when the police was deserving/taking into account the perspectives of the victims. In this case deserving means that the police was taking the victims' concerns seriously, they were not blaming the victims, and instead they were trying to understand the situation from the victims' perspectives. A third dimension was the proactive versus pro-forma response of the police. Proactive police responses were those entailing active measures to ensure victim safety and empowerment. In contrast, pro-forma responses were police responses that consisted of minimal intervention or even avoidance of required intervention (Russell and Light 2006).

According to the provisions of the Criminal Code for the crimes of assault and battery committed against a family member the indictment is conditioned by the complaint of the aggrieved person, except for crimes of severe personal injury, of death causing injuries and murder, in these cases the indictment is made by default ${ }^{2}$. The criminal proceeding for crimes punishable on the injured person's preliminary complaint is however governed by the principle of availability. This means that the injured person may decide to withdraw the preliminary complaint or, when possible, to reconcile with the offender, a situation which stops the previously started criminal proceedings, even if it was started by default, except in case of severe personal injury (Radu and Radu 2004) ${ }^{3}$.

According to our findings many women withdrew their complaints for different reasons (e.g. fear of violence escalation, financial and/or emotional dependency on the offender). The results of other studies regarding

\footnotetext{
2 With regard to the crime of hitting or other forms of violence, article 180 para. 3 of the Romanian Criminal Code reads as follows: 'Criminal action is initiated upon prior complaint from the injured person. For the acts in para. 1 and 2 criminal action may also be initiated ex officio.' Paragraphs 1 and 2 refer to the acts of hitting or other forms of violence which are committed against family members. Also, with regard to the crime of bodily harm, which is provided for in art 181 of the Romanian Criminal Code, the second paragraph of art 181 reads as follows: 'Criminal action is initiated upon prior complaint from the injured person. For the acts in para. 1, criminal action may also be initiated ex officio.' For both crimes, the Criminal Code stipulates that: 'Reconciliation of parties removes criminal liability, and it also takes effect in cases in which the criminal action was initiated ex officio.' (art. 180 para. 4 and art 181 para. 3, The Criminal Code).

3 Art. 131 of the Criminal Code reads as follows: 'In the case of an offence for which the initiation of criminal action is conditioned by the lodging of a criminal complaint from the injured person, the lack of such a complaint removes the criminal responsibility.'
} 
withdrawal show that some victims did not want the abusers to be arrested and indicated that they would not call the police again for fear of future arrest of the abusers. Sometimes the request for legal intervention is based on victims' desire for the presence of police officers to stop the abuse but not to arrest the abuser (Johnson 2007).

Besides the withdrawal of the preliminary complaints many files are closed by the police and the prosecution office for lack of evidence. The lack of evidences is the specificity of these cases. APFR (2006) in their research shows that in more than $50 \%$ of the cases they analysed there were no evidences. Our findings show that many women were not even informed about any following action of the police or of the prosecution service. As we saw, there were only two women who went to the court, in both of the cases the punishment was a fine.

Courts tend to minimize the seriousness of domestic violence related crimes and apply reduced penalties even in situations where the specific gravity of the crime is high, and in the case of first act of assault or battery, the punishment consists of a fine and it is usually suspended ${ }^{4}$. Although this type of crime is very frequently met in practice, only a few cases are brought to court (Bureau of Democracy, Human Rights and Labor from US Department of State 2008).

\footnotetext{
${ }^{4}$ As stated by the law, the penalty upon conviction for committing the crime of hitting or other forms of violence causing physical suffering to family members is 6 months' - 1 year's imprisonment or a fine (art. 180 para. $1^{1}$ ). If the above-mentioned crime causes an injury that needs medical care of up to 20 days, the penalty provided by the law is 1-2 years' imprisonment or a fine (art. 180 para $2^{1}$ ). For bodily harm caused to a family member needing up to 60 days of medical care, the law prescribes a term of imprisonment from one to 5 years (art. 181 para $1^{1}$ The Criminal Code). The suspended prison sentence is provided for in art 81 of the Criminal Code, which reads as follows: 'The Court may order the suspension of the prison sentence for a certain period of time, if the following conditions are met: a.) the penalty applied is no more than 3 years or a fine b.) the offender has not been previously sentenced to a penalty of imprisonment of more than 6 months, except for the cases when the conviction falls under the situations provided for in Art 38 c.) it is deemed that the purpose of the penalty can be attained even without it being served. A suspended prison sentence may also be applied to a concurrence of offences, if the penalty on conviction is imprisonment of no more than 2 years and the conditions of para. (1) b) and c) are met.'
} 


\section{Conclusions}

Our research shows the complex relationship that exists between victims' needs, especially their need for safety, and criminal justice outcomes. The 'justice gap' is huge. Many cases are lost at different levels of the criminal justice system. To reduce this gap, obvious changes are needed in terms of criminal justice policies and culture.

In order for women to benefit from protection there is a need for a complex and coordinated intervention from the agencies involved (police, family support, the involvement of social services, DGASPC - The General Directorate of Social Assistance and Child Protection), legal information and long term support for the victims.

Women expect the representatives of the criminal justice system to intervene rapidly, immediately, to apply efficient safety measures, such as the evacuation of the offender in crisis situations, issuing a restraining order against the perpertrator so that he would not approach the house, or go back to the house, and collaboration with the professionals of DGASPC. Women do not usually want the perpetrator to go to prison, with the exception of severe forms of violence, but they want to trust the criminal justice system and they want justice to be done.

From the point of view of the decision making process regarding the collaboration with the criminal justice system, children's response have a huge influences on the women's decision. The way women perceive the influence it will have the involvement of the criminal justice system on the welfare and the safety of the children is of vital importance (this will also influence the decision to make an emergency call, to file a complaint, etc.).

A woman's decision to remain in or leave a violent situation, to report domestic violence, to collaborate with the criminal justice system depends on her needs, on the alternatives available (social, legal) and on the support received. These needs change during the course of the intervention. Using the criminal justice system represents a stress factor, can cause many frustrations (e.g. move to a shelter, collaborate with police and with child protection services, prepare for the trial, need for financial resources etc.). The women, who went through with the criminal trial, were among those who benefited from long term professional support from an independent counsellor working in the frame of an NGO. Furthermore, for the women it 
is important to involve and to inform them at every stage of the intervention as they constantly refer to the multiple safety need: physical, emotional, economical.

Generally the changing of police practices and cultural changes can be difficult to achieve (Hester 2005). Our research shows that police intervention is felt to be inadequate because it does not provide the safety that these women need. More often than not the police perceive domestic violence as a personal, family problem and by not stepping in or by reducing the intervention to paying a fine they achieve one goal only, namely, to discourage these women from any future contact with the criminal justice system. However, by comparison with the research conducted in 2000, Victimele Violenței Domestice (Muntean, Popescu and Popa 2000) our results indicate that police treatment in some of the situations had a positive turn, some victimized women felt supported by the police as a result of their being treated (in some cases) with seriousness and respect. Even if the outcome of police intervention generally was not efficient in terms of safety or further violence, women felt encouraged by the positive attitude of the police as a result of the concern, support and information they got from policemen. This highlights the importance of nonlegislative factors of criminal justice intervention.

\section{Acknowledgements}

We would like to thank the research team and also our associate partners, who through their help and their work have enabled us to bring this project to fruition: international WOSAFEJUS team, 'Alternative Sociale' Association Iaşi, Cluj County Police Inspectorate, General Directorate of Social Assistance and Child Protection Cluj, The Public Prosecutor's Office attached to the Courthouse of Cluj Napoca, the Courthouse of Cluj Napoca, DAS Cluj Napoca, SPAS Turda. We would like to thank also the women, victims of domestic violence who collaborate with us and shared their experiences.

\section{References:}

Agenția Națională pentru Protecția Familiei. Statistici 2009. http:/ / www.anpf.ro

APFR. 2006. Drepturile Femeii: între UZ şi ABUZ! Monitorizarea presei şi justitiei locale şi regionale. Raport de cercetare.

Bailey, Kimberly. 2010. Lost in translation: domestic violence, "the personal is political" and the criminal justice system. The Journal of Criminal Law E Criminology 100 (4): 1255-1300. 
Bureau of Democracy, Human Rights and Labor from US Department of State. 2008. Country Reports on Human Rights Practices, 2008 Human Rights Report: Romania.

http://www.state.gov/g/drl/rls/hrrpt/2008/eur/119100.htm

Center for Partnership and Equality. 2003. The National Research on Domestic Violence and Violence in the Workplace.

http://www.gender.ro

Consiliul Suprem al Magistraților. 2010. Statistici - Document intern.

Davis, Robert C. and Barbara Smith. 1995. Domestic violence reforms: Empty promises or fulfilled expectations? Crime and Delinquency 41 (4): 541552.

Felson, Richard B., Steven F. Messner, Anthony W. Hoskin and Glenn Deane. 2002. Reasons for reporting and not reporting domestic violence to the police. Criminology 40 (3): 617-647.

Gallup Organization. 2000. Gender Barometer. Open Society Foundation.

Gallup Organization. 2003. Survey on Violence Against Women in Bucharest.

http://www.gallup.ro/download/VAW-Bucharest_2003.pdf

Garner, Joel H. and Christopher D. Maxwell. 2000. What Are the Lessons of the Police Arrest Studies? Journal of Aggression, Maltreatment $\mathcal{E}$ Trauma 4 (1): 83-114.

Hester, Marianne. 2005. Making it through the Criminal Justice System: Attrition and Domestic Violence. Social Policy E Society 5 (1): 79-90.

Johnson, Ida M. 2007. Victims' perceptions of police response to domestic violence incidents. Journal of Criminal Justice 35 (5): 498-510.

Ministry of Health, World Bank, UNFPA, USAID, UNICEF. 2005. Reproductive Health Survey, Romania 2004, Summary Report. Buzău: Alpha MDN.

Mitrache, Constantin and Cristian Mitrache. 2009. Drept penal român. Partea generală. Bucureşti: Universul Juridic.

Muntean, Ana, Marciana Popescu and Smaranda Popa. 2000. Victimele violenței domestice: copiii şi femeile. Timişoara: Eurostampa.

Popescu, Marciana and Ana Muntean. 2000. Violența domestică - de la realitate importanta la asumarea unei stări de fapt. In Un deceniu de tranziție - situația copilului şi a familiei în România. Bucureşti: UNICEF.

Radu, Mariana Narcisa and Mihnea-Dan Radu. 2004. Considerații privind legea pentru prevenirea şi combaterea violenței în familie. In Studii şi cercetări din domeniul ştiințelor socio-umane. Vol. 12. Cluj-Napoca: Argonaut.

Roth, M. 2005. Copii şi femei victime ale violenței. Cluj-Napoca: Presa Universitară Clujeană.

Russell, Mary and Linda Light. 2006. Police and Victims Perspectives on Empowerment of Domestic Violence Victims. Police Quarterly 9 (4): 375-396. 
Sherman, Lawrence W. and Richard A. Berk. 1984. The specific deterrent effects of arrest for domestic assault. American Sociological Review 49 (2): 261-272.

* * *. 2010. Codul Penal. Monitorul Oficial nr. 714. October 26.

* * *. 2010. Codul de Procedură Civilă. Monitorul Oficial nr. 714. October 26.

* * *. 2010. Codul de Procedură Penală. Monitorul Oficial nr. 486. July 15.

* * *. 2003. Legea 217/2003. Monitorul Oficial nr. 367. May 29. 